\title{
Diaphragmatic angiogenic growth factor mRNA responses to increased ventilation caused by hypoxia and hypercapnia
}

\author{
N.M. Siafakas*,\#, M. Jordan*, H. Wagner*, E.C. Breen*, H. Benoit*, P.D. Wagner*
}

\begin{abstract}
Diaphragmatic angiogenic growth factor $m R N A$ responses to increased ventilation caused by hypoxia and hypercapnia. N.M. Siafakas, M. Jordan, H. Wagner, E.C. Breen, H. Benoit, P.D. Wagner. (C) ERS Journals Ltd 2001.

ABSTRACT: This study investigates the effect of increased ventilation on the expression of messenger ribonucleic acid (mRNA) levels of vascular endothelial growth factor (VEGF), basic fibroblast growth factor (bFGF) and transforming growth factor$\beta_{1}\left(\right.$ TGF $\left.-\beta_{1}\right)$ in the diaphragm of intact, awake, spontaneously breathing rats, compared with responses in paralysed, mechanically-ventilated animals at similar blood gas and ventilatory levels.

Four groups of intact, rats were studied in a body box, each group breathing one of four gases: room air, $12 \%$ oxygen $\left(\mathrm{O}_{2}\right), 5 \%$ carbon dioxide $\left(\mathrm{CO}_{2}\right)$, or $12 \% \mathrm{O}_{2}+5 \% \mathrm{CO}_{2}$ for $1 \mathrm{~h}$. Another 4 groups of paralysed, mechanically-ventilated animals were matched for arterial blood gas and ventilatory level.

The results showed that VEGF mRNA abundance was increased three-fold and that of bFGF 1.5-fold when $12 \% \mathrm{O}_{2}+5 \% \mathrm{CO}_{2}$ were breathed, but TGF- $\beta_{1}$ did not change. A significant linear relationship of VEGF and bFGF mRNA to minute ventilation was observed in awake animals $(r=0.98, p<0.02$ and $r=0.87, p<0.03$, respectively). The paralysed, mechanically-ventilated animals showed no mRNA increases for any probe. Systemic hypoxia had no additional effect on VEGF or bFGF levels in the diaphragm.

It was concluded that messenger ribonucleic acid for vascular endothelial growth factor and basic fibroblast growth factor in the diaphragm rises significantly as a result of active ventilation and not due to blood gas/pH changes or to passive muscle shortening per se.

Eur Respir J 2001; 17: 681-687.
\end{abstract}

*Dept of Medicine, University of California, San Diego La Jolla, CA, USA. ${ }^{\#}$ Dept of Thoracic Medicine, University of Crete, Heraklion, Greece.

Correspondence: N.M. Siafakas, Dept of Thoracic Medicine, Medical School, University of Crete, Heraklion, Greece. Fax: 3081542650

Keywords: Angiogenesis basic fibroblast growth factor diaphragm respiratory muscles transforming growth factor- $\beta 1$ vascular endothelial growth factor

Received: October 141999 Accepted after revision November 7 2000

This study was supported by a research grant from the National Institute of Health, Heart and Lung (USA) grant No. NIH HL17731.
It is well known that a major adaptation of skeletal muscles to repeated exercise (endurance training) is the formation of new capillaries (angiogenesis) [1-3]. Angiogenesis is an extremely complex process involving, among other steps dissolution of extracellular matrix underlying the endothelium, cell migration and endothelial cell proliferation [4, 5]. In malignant tumour growth or in development, it has been shown that factors such as vascular endothelial growth factor (VEGF), basic fibroblast growth factor (bFGF) and transforming growth factor- $\beta_{1}\left(\mathrm{TGF}-\beta_{1}\right)$ are involved in the formation of new capillaries [6-8].

It has been shown that a single, 1 -h bout of exercise of normal skeletal muscles increases the messenger ribonucleic acid (mRNA) levels of VEGF, bFGF and TGF- $\beta_{1}$ [9] (more so in hypoxia for VEGF, in particular). In addition, electrical stimulation increases VEGF levels [10]. Recently, it was demonstrated that passively-induced hyperperfusion does not increase muscle VEGF mRNA, and it was speculated that either intracellular hypoxia or mechanical effects of contraction per se (such as fibre stretch) may be responsible for this increase [11].

The respiratory muscles are skeletal muscles and respond to endurance training by increasing their capillary density, as do the locomotive muscles. However, the diaphragm differs from locomotive skeletal muscles in that it continuously and rhythmically contracts, and thus it is subjected to life long "endurance training". These findings have accordingly focused the authors attention on the capillary growth of the respiratory muscles in response to contraction, and particularly that of the diaphragm. Since it is well known that respiratory muscle failure is a life-threatening condition, it is of importance to understand the regulation of capillary growth of the respiratory muscles. In addition, patients in intensive care units (ICUs) are usually mechanically ventilated for some time. It is thus possible that a lack of active respiratory muscle effort under these conditions could reduce respiratory muscle capillarity, which could contribute to difficulty in respiratory weaning.

The aim of this study was to investigate the response of VEGF, bFGF and TGF- $\beta_{1}$ mRNA in the diaphragm to increased ventilation stimulated by hypoxia and/or hypercapnia. These responses were compared with those of paralysed, mechanically-ventilated animals at similar blood gas and ventilatory levels, to determine whether active contraction, passive movement or altered partial pressure of oxygen $\left(\mathrm{PO}_{2}\right)$ is primarily responsible for changes in mRNA.

It was demonstrated that mRNA levels of VEGF and bFGF were increased after $1 \mathrm{~h}$ of exposure to these stimuli and that this rise was proportional to minute 
ventilation. Paralysed, mechanically-ventilated animals showed no mRNA change, for any angiogenic factor, suggesting that neither passive shortening nor hypoxia were involved. The possible clinical implications of these findings are discussed.

\section{Methods}

Adult female Wistar rats were used throughout the study. Forty-eight animals were studied (mean \pm sD age $9.2 \pm 1.1$ weeks and weight $272 \pm 13 \mathrm{~g}$ ). The study was approved by the Animal Subjects Committee of the University of California, San Diego, USA.

\section{Protocol I: intact animals}

Four groups of six animals each were studied. An arterial line (PE-50) was placed in the femoral artery under short duration halothane anaesthesia, using sterile techniques. The catheter was positioned under the skin and exited at the back of the neck of the animal. The catheter was heparinized, capped and the animal was allowed to recover from anaesthesia for at least $24 \mathrm{~h}$. The next day, the intact animal was comfortably positioned into a body box $(30 \mathrm{~cm} \times 18 \mathrm{~cm})$. The arterial line was connected to an airtight opening of the box in order to withdraw arterial blood samples during the experiments. The animals spontaneously breathed room air for 10-20 min (baseline conditions), and measurements of ventilator parameters (tidal volume $(V \mathrm{~T})$ and respiratory frequency $(f \mathrm{R})$ ) were made according to the method of BARTLETT and TENNEY [12]. Minute ventilation $V^{\prime} E$ was calculated using the equation $V^{\prime} \mathrm{E}=V \mathrm{~T} \times f \mathrm{R}$. In addition, an arterial blood sample $(1 \mathrm{~mL})$ was taken for the measurement of blood gases (Instrumentation Laboratories, Model 1306). Thereafter, the animal spontaneously breathed either room air $\left(\mathrm{A}=\right.$ control group) or $12 \% \mathrm{O}_{2}+88 \% \mathrm{~N}_{2}$ ( $\mathrm{B}=$ hypoxic group), or $5 \% \quad \mathrm{CO}_{2},+21 \% \mathrm{O}_{2}+74 \% \mathrm{~N}_{2}$ (C=hypercapnic group) or $12 \% \mathrm{O}_{2}+5 \% \mathrm{CO}_{2}+83 \% \mathrm{~N}_{2}$ ( $\mathrm{D}=$ hypoxic + hypercapnic group) for $1 \mathrm{~h}$. The concentrations of the inspired gases in the body box were continuously measured by a mass spectrometer (Perkin Elmer MGA 1100; Perkin Elmer, Saira Louis, MO, USA).

Measurements of $V \mathrm{~T}, f \mathrm{R}$, and blood gases were made after 30, 45 and $60 \mathrm{~min}$ of breathing the various mixtures. After $1 \mathrm{~h}$ of exposure to the designated gas, the animals were euthanized by administrating $1 \mathrm{~mL}$ of pentobarbital sodium via the arterial line. The diaphragm was immediately removed and quickly frozen in liquid nitrogen for isolation of total cellular mRNA.

Protocol II: Anaesthetized, paralysed, mechanicallyventilated animals.

Another four groups of animals (six each) were anaesthetized with intraperitoneal pentobarbital sodium $\left(40 \mathrm{mg} \cdot \mathrm{kg}^{-1}\right)$ and paralysed with pancuronium promide i.v. $\left(2 \mathrm{mg} \cdot \mathrm{kg}^{-1}\right)$ The animals were tracheostomized and mechanically-ventilated by a rodent ventilator (Har- vard \# 683; Harvard, Boston, MA, USA). The dead space of the connecting tubing was $<1 \mathrm{~mL}$. In addition, an arterial catheter was placed into the femoral artery. The ventilator was set to produce a minute ventilation equivalent to that of the intact animals of protocol I during quiet room air breathing in order to match their blood gases. After $15 \mathrm{~min}$ baseline measurements, the animals breathed room air (control) or $12 \% \mathrm{O}_{2}+88 \%$ $\mathrm{N}_{2}$ (hypoxic), or $5 \% \mathrm{CO}_{2}+21 \% \mathrm{O}_{2}+74 \% \mathrm{~N}_{2}$ (hypercapnic), or $12 \% \mathrm{O}_{2}+5 \% \mathrm{CO}_{2}+83 \% \mathrm{~N}_{2}$ (hypoxic+hypercapnic), gas mixtures. Again, the ventilator was set $\left(f \mathrm{R}\right.$ and $\left.V^{\prime} \mathrm{T}\right)$ to match the ventilatory levels of the intact animals and their blood gases at each corresponding experimental condition of Protocol I. After $1 \mathrm{~h}$ of mechanical ventilation, the animals were euthanized, and the diaphragm was removed and processed as in the intact, spontaneously breathing animals (Protocol I).

\section{Ribonucleic acid isolation and Northern blot analysis}

Total cellular ribonucleic acid (RNA) was isolated from each muscle sample by the method of CHOMCZYNSKI and SACCHI [13]. RNA preparations were quantitated by absorbance at $260 \mathrm{~nm}$, and intactness was assessed by ethidium bromide staining. Ten micrograms of total cellular RNA were separated by electrophoresis in $6.6 \%$ formaldehyde- $1 \%$ agarose gel. Fractionated RNA was transferred by Northern blot to a Zeta probe membrane (Bio-Rad, Hercules, CA, USA). RNA was cross-linked to the membrane by ultraviolet irradiation by using an ultraviolet crosslinker (model FD-UVXL 1000; Fisher Scientific, Hampton, NH, USA) and stored at $4^{\circ} \mathrm{C}$. The blots were then probed with oligolabelled [a- ${ }^{32}$ Phosphorus] deoxycytidine triphosphate complementary deoxyribonucleic acid (cDNA) probes, which had a specific activity of $\geqslant 1 \times 10^{9}$ disintegrations $\cdot \mathrm{min}^{-1} \cdot \mu \mathrm{g} \mathrm{DNA}^{-1}[14]$. The human VEGF probe is a $0.93-\mathrm{k}$ cDNA fragment isolated from the EcoR I site of pUC-derived plasmid [6]. The human TGF- $\beta_{1}$ cDNA probe is a $0.985-\mathrm{kb}$ Hind III.Xba I insert cloned into pBlue-script II $\mathrm{KS}^{+}$ vector [15]. The bFGF probe is a $1-\mathrm{kb}$ Xho I fragment of human bFGF cDNA [5]. Prehybridization and hybridizations were performed in $50 \%$ formamide, $5 \mathrm{X}$ SSC (20X SSC is $0.3 \mathrm{M}$ sodium chloride and $0.3 \mathrm{M}$ sodium citrate), 10X Denhardt's solution (100X Denhardt's solution is 2\% Ficoll and 2\% polyvinyl pyrrolidone), $50 \mathrm{mM}$ sodium phosphate ( $\mathrm{pH} 6.5), 1 \%$ SDS, and $250 \mu \mathrm{g} \cdot \mathrm{mL}^{-1}$ of sonicated salmon sperm DNA at 37 or $42^{\circ} \mathrm{C}$. Blots were washed with $2 \mathrm{X}$ SSC and $0.1 \%$ SDS at room temperature, with O.1X SSC and $0.1 \% \mathrm{SDS}$ at $55^{\circ} \mathrm{C}$ for the VEGF mRNA, and with $1 \mathrm{X} \mathrm{SSC}$ and $0.1 \% \mathrm{SDS}$ at $60^{\circ} \mathrm{C}$ for TGF- $\beta_{1}$ and $\mathrm{bFGF}$ mRNAs. Blots were exposed to XAR-5 radiograph film (Eastman Kodak, New Haven, CT, USA) by use of a Cronex Lightning Plus screen at $-70^{\circ} \mathrm{C}$. In all analyses, quantitative densitometry of the autoradiographs was used to measure the mRNA levels for all three growth factors. Each blot was subsequently reprobed (after prior complexes were stripped) with a cDNA specific for $18 \mathrm{~S}$ ribosomal RNA, and this signal was used to normalize the mRNA signal for minor variation in the lane loading. 


\section{Statistical analysis}

In all statistical treatments, quantitative densitometry of measured mRNA levels for all three growth factors was used. Lane loading variability was controlled by the normalization of the signals with the ribosomal $18 \mathrm{~S}$ RNA as the control band. A one-way analysis of variance was used to determine changes in mRNA levels with increased ventilation. Linear relationships were tested with the least square method, and the MannWhitney test was used to determine differences between awake intact (I) and paralysed ventilated (P) animals. Statistical significance was accepted if $\mathrm{p} \leqslant 0.05$.

\section{Results}

The results of the ventilatory parameters $\left(V \mathrm{~T}, f_{\mathrm{R}}, V^{\prime} \mathrm{E}\right)$ and of the blood gases $(\mathrm{pH}$, oxygen tension in arterial blood $\left(\mathrm{Pa}_{\mathrm{a}} \mathrm{O}_{2}\right)$, carbon dioxide tension in arterial blood $\left(P \mathrm{a}, \mathrm{CO}_{2}\right)$ in the awake, intact (I) spontaneously breathing and in the paralysed $(\mathrm{P})$, mechanically-ventilated animals are summarized in table 1 . No statistically significant differences were found in the mean values of the variables discussed between the intact (I) and paralysed (P) animals breathing the same gas mixture. Although, the mean $\mathrm{pH}$ value in paralysed animals was lower (7.28) than the one in intact (I) (7.38) during hypoxic+hypercapnic runs, suggesting a mild metabolic acidosis, those differences were not significant. Therefore, the experimental requirements to test the intact and paralysed animals under similar ventilatory levels, blood gases and acid-base conditions were met. In addition, table 1 shows that minute ventilation $\left(V^{\prime} \mathrm{E}\right)$ increased significantly due to hypoxia and/or hypercapnia in the spontaneously breathing animals.

Figure 1 shows the set of Northern blots of VEGF, bFGF and TGF- $\beta_{1}$ mRNA levels in the diaphragm

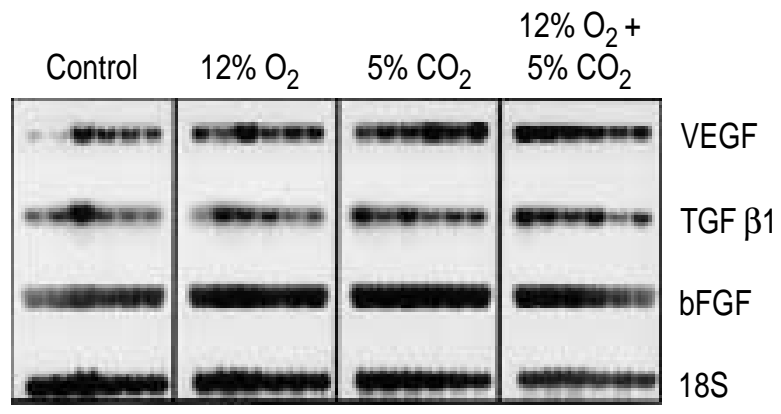

Fig. 1. - Northern blots of vascular endothelial growth factor (VEGF), transforming growth factor $\beta$ (TGF- $\beta$ ), basic fibroplast growth factor (bFGF) normalized to $18 \mathrm{~S}$ ribosomal RNA (Rn 18S) in awake, spontaneously breathing animal: control (room air), hypoxic $\left(12 \% \mathrm{O}_{2}\right)$, hypercapnic $\left(5 \% \mathrm{CO}_{2}\right)$ and hypoxic and hypercapnic $\left(12 \% \mathrm{O}_{2}+5 \% \mathrm{CO}_{2}\right)$ conditions.

from protocol I in intact spontaneously breathing animals after $1 \mathrm{~h}$ of increased ventilation caused by hypoxia and/or hypercapnia. It is apparent that with hypoxia and/or hypercapnia VEGF and bFGF mRNA abundance was increased.

The Northern blots of the same angiogenic factors from protocol II where the animals were anaesthetized, paralysed and mechanically-ventilated are shown in figure 2. It can be seen that no apparent change of VEGF occurred during those experimental conditions.

The normalized values of mRNA for VEGF, bFGF and TGF- $\beta_{1}$ in the diaphragm of the intact animals (protocol I) and the paralysed, mechanically-ventilated animals (protocol II) are shown in figure 3. VEGF mRNA increased more than 2.5-fold from the control condition (breathing room air) in the intact spontaneously breathing animals after $1 \mathrm{~h}$ of increased ventilation $\left(5 \% \mathrm{CO}_{2}\right.$ plus $\left.12 \% \mathrm{O}_{2}\right)$. Similarly, bFGF increased approximately 1.5 -fold, and both increases were statistically significant $(p<0.0017$ and $p<0.001$

Table 1. - Ventilatory parameters and blood gases (mean $\pm \mathrm{SD}$ ) in intact (I) awake spontaneously breathing and in paralysed $(P)$ mechanically-ventilated animals

\begin{tabular}{|c|c|c|c|c|}
\hline \multirow[b]{2}{*}{ Ventilatory parameter } & \multicolumn{4}{|c|}{ Inspired mixtures } \\
\hline & $\begin{array}{l}\text { Control } \\
\text { (room air) }\end{array}$ & $\begin{array}{l}\text { Hypoxia } \\
\left(12 \% \mathrm{O}_{2}\right)\end{array}$ & $\begin{array}{l}\text { Hypercapnia } \\
\left(5 \% \mathrm{CO}_{2}\right)\end{array}$ & $\begin{array}{l}\text { Hypoxia+hypercapnia } \\
\left(12 \% \mathrm{O}_{2}+5 \% \mathrm{CO}_{2}\right)\end{array}$ \\
\hline \multicolumn{5}{|l|}{$V \mathrm{~T} \mathrm{~mL}$} \\
\hline I & $0.526 \pm 0.81$ & $0.797 \pm 0.23$ & $0.941 \pm 0.21$ & $1.160 \pm 0.18$ \\
\hline $\mathrm{P}$ & $0.510 \pm 0.11$ & $0.800 \pm 0.26$ & $0.910 \pm 0.26$ & $1.100 \pm 0.2$ \\
\hline \multicolumn{5}{|l|}{$f$ beats $\cdot \min ^{-1}$} \\
\hline I & $82 \pm 12$ & $99 \pm 15$ & $128 \pm 12$ & $146 \pm 23$ \\
\hline \multirow{2}{*}{\multicolumn{5}{|c|}{$V^{\prime} \mathrm{E} \mathrm{mL} \cdot \mathrm{min} \cdot \mathrm{kg}^{-1}$}} \\
\hline & & & & \\
\hline I & $163 \pm 30$ & $278 \pm 87$ & $480 \pm 19$ & $610 \pm 141$ \\
\hline $\mathrm{P}$ & $164 \pm 41$ & $280 \pm 35$ & $387 \pm 77$ & $503 \pm 54$ \\
\hline \multicolumn{5}{|l|}{$\mathrm{pH}$} \\
\hline $\mathrm{I}$ & $7.46 \pm 0.04$ & $7.53 \pm 0.02$ & $7.36 \pm 0.02$ & $7.38 \pm 0.03$ \\
\hline $\mathrm{P}$ & $7.44 \pm 0.02$ & $7.47 \pm 0.08$ & $7.33 \pm 0.02$ & $7.28 \pm 0.05$ \\
\hline \multicolumn{5}{|l|}{$\mathrm{Pa}_{\mathrm{a}, \mathrm{O}_{2} \mathrm{mmHg}}$} \\
\hline I & $95.0 \pm 8.4$ & $44.8 \pm 1.8$ & $118.0 \pm 2.8$ & $68.0 \pm 4.2$ \\
\hline $\mathrm{P}$ & $82.0 \pm 2.3$ & $42.7 \pm 5.5$ & $117.0 \pm 8.6$ & $55.0 \pm 5.3$ \\
\hline \multicolumn{5}{|l|}{$\mathrm{Pa}_{\mathrm{a}} \mathrm{CO}_{2} \mathrm{mmHg}$} \\
\hline I & $34 \pm 3.8$ & $29 \pm 0.8$ & $44 \pm 2.1$ & $42 \pm 1.2$ \\
\hline $\mathrm{P}$ & $32 \pm 4.2$ & $25 \pm 3.3$ & $45 \pm 1.5$ & $43 \pm 1.9$ \\
\hline
\end{tabular}

No significant difference between I and $\mathrm{P}$ was observed in any of the above parameters. 


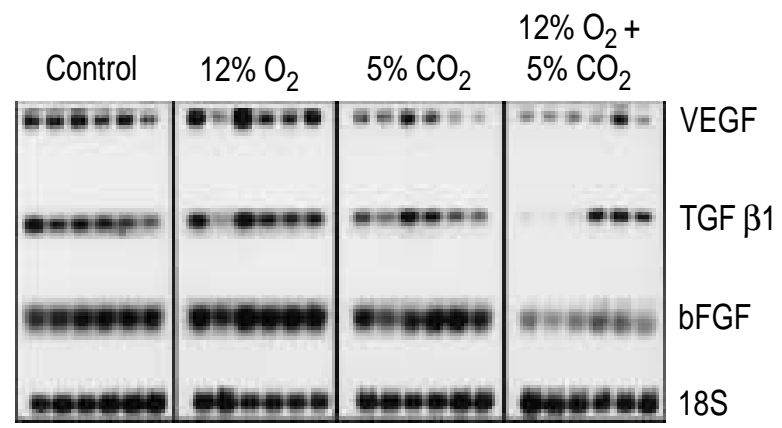

Fig. 2. - Northern blots of vascular endothelial growth factor (VEGF), basic fibroblast growth factor (bFGF), transforming growth factor (TGF- $\beta 1$ ) and normalized to RN18S. In anaesthetized, paralysed and mechanically-ventilated animals.

respectively), with increased ventilation. In contrast, TGF- $\beta_{1}$ mRNA levels did not change after $1 \mathrm{~h}$ breathing under the four experimental conditions in the intact animals (fig. 3).

No significant change in any of the three growth factor mRNA levels was observed in the paralysed animals when they were mechanically-ventilated at high ventilatory levels (similar to those in intact animals) and with similar $\mathrm{pH}$ and blood gases. A trend towards an increase in mRNA levels of the three factors was seen in the paralysed animals during hypoxia (fig. 3, hatched bars), but this did not reach statistical significance. The mRNA level of bFGF during hypoxia and hypercapnia (fig. 3, hatched bar) actually decreased.

Figure $4 \mathrm{a}$ shows the relationship between minute ventilation $\left(V^{\prime} \mathrm{E}\right)$ and the mean normalized mRNA levels of VEGF, bFGF and TGF- $\beta_{1}$, in the diaphragm. A statistically significant linear relationship was found between $V^{\prime} \mathrm{E}$ and VEGF $(\mathrm{r}=0.98, \mathrm{p}<0.02)$ and between $V^{\prime} \mathrm{E}$ and $\mathrm{bFGF}(\mathrm{r}=0.87, \mathrm{p}<0.03)$ but not between $V^{\prime} \mathrm{E}$ and TGF- $\beta_{1}$.

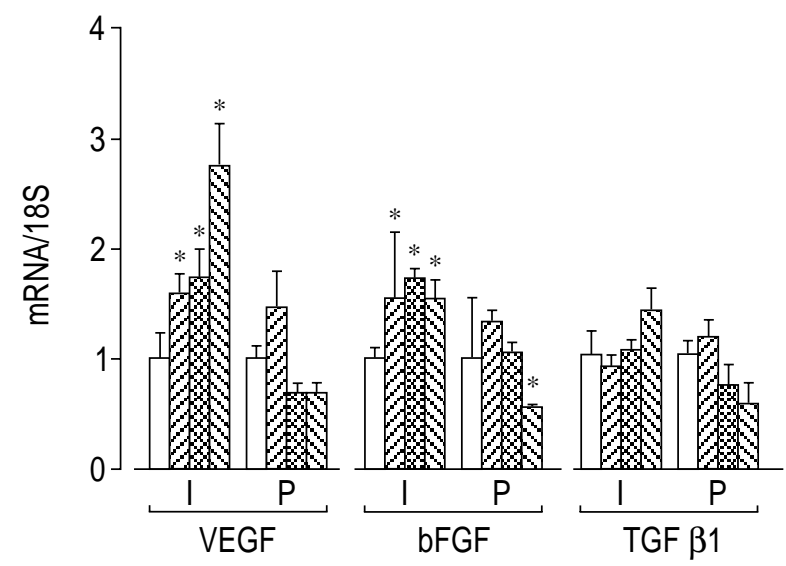

Fig. 3. - Mean \pm SEM values of normalized messenger ribonucleic acid (mRNA) of vascular endothelial growth factor (VEGF), basic fibroblast growth factor (bFGF), transforming growth factor (TGF- $\beta 1)$ in the diaphragm of intact, awake, spontaneously breathing (I) and anaesthetized paralysed (P), mechanically-ventilated animal breathing. $\square$ : room air; $\mathbb{Z}: 12 \% \mathrm{O}_{2} ;$ : $5 \% \mathrm{CO}_{2}$ and $\mathbb{N}: 12 \% \mathrm{O}_{2}+5 \% \mathrm{CO}_{2}$. $*$ : significantly different from room air.
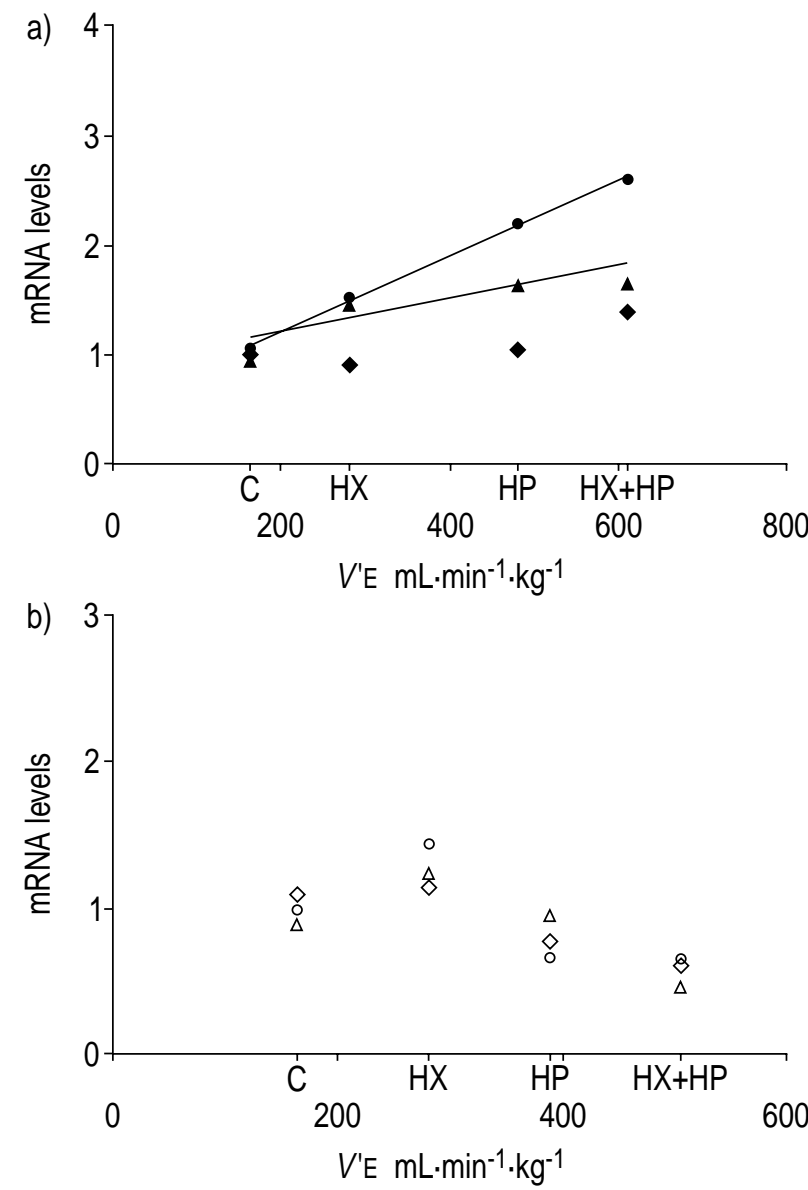

Fig. 4. - Relationship between minute ventilation $\left(V^{\prime} \mathrm{E}\right)$ and mean messenger ribonucleic acid (mRNA) levels of vascular endothelial growth factor, basic fibroblast growth factor and transforming growth factor- $\beta 1$ in the diaphragm under control, hypoxic and/or hypercapnic conditions. a) in awake, intact, spontaneously breathing animals; b) in paralysed mechanically-ventilated animals. : VEGF intact $(\mathrm{r}=0.980, \mathrm{p}<0.002) ; \boldsymbol{\Delta}: \mathrm{bFGF}$ intact $(\mathrm{r}=0.870, \mathrm{p}<0.03)$; $: \mathrm{TGF}-\beta 1$ intact (nonsignificant; NS); $\bigcirc$ : VEGF paralysed (NS); $\triangle$ : bFGF (NS); $\diamond:$ TGF- $\beta 1$ (NS).

No significant relationship was observed between VE and mRNA abundance of the three growth factors in the paralysed ventilated animals (fig. $4 \mathrm{~b}$ ).

Finally, no significant relationship was found between mRNA levels and $\mathrm{Pa}, \mathrm{O}_{2}, \mathrm{~Pa}_{2} \mathrm{CO}_{2}$, (fig. 5) or arterial $\mathrm{pH}$ in the intact, awake, spontaneously breathing or paralysed animals.

\section{Discussion}

The main findings of this study were that mRNA levels for VEGF and bFGF in the diaphragm increase after $1 \mathrm{~h}$ of actively increased ventilation, and do so in proportion to ventilation, but are unrelated to $P \mathrm{a}, \mathrm{O}_{2}$ and $P$ a,$C_{2}$. Those for TGF- $\beta_{1}$ did not change under the same experimental conditions.

The design of this study has allowed for the assessment of the separate role of: a) active contraction; b) systemic hypoxaemia; and c) passive muscle shortening during mechanical ventilation on the growth 

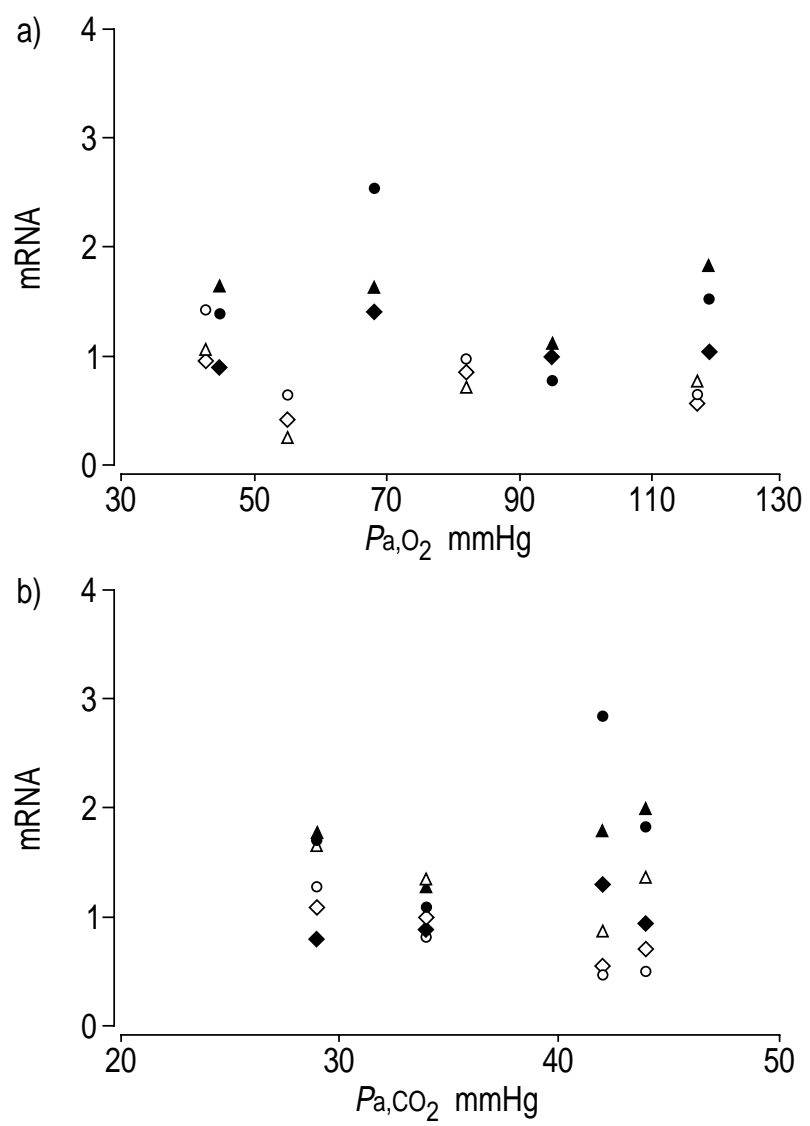

Fig. 5. - Plots of messenger ribonucleic acid (mRNA) levels of vascular endothelial growth factor (VEGF; - $\bigcirc$ ), basic fibroblast growth factor (bFGF; $\boldsymbol{\Delta}, \triangle$ ) and transforming growth factor (TGF- $\beta 1 ; \diamond, \diamond)$ versus arterial oxygen tension $\left(\mathrm{Pa}_{\mathrm{a}} \mathrm{O}_{2}\right)$ in intact (closed) and paralysed (open symbols) animals under control, hypoxic and/or hypercapnic conditions. b) Similar plots of mRNA levels of VEGF, bFGF and TGF- $\beta 1$ versus arterial carbon dioxide tension $\left(\mathrm{Pa}_{\mathrm{a}}, \mathrm{CO}_{2}\right)$ in intact and paralysed animals. None of the above relationships were statistically significant.

factor gene response. Based on the authors prior work in locomotor skeletal muscle [9, 16-19], showing an enhanced mRNA response of VEGF to hypoxia, studying paralysed, ventilated animals as controls with similar blood gas values as the actively breathing animals provided the means of distinguishing a) from b). Unlike locomotor skeletal muscle, systemic hypoxia alone did not stimulate mRNA levels of the diaphragm during the paralysed experiments. Accordingly, the data suggest that for the diaphragm, active contraction is required for increased gene expression and that hypoxia per se is not contributory. The other conclusion that can be made from the paralysed control animals was that passive hyperventilation and thus fibre shortening can also be ruled out as contributing to the gene response. Why the diaphragm appears unresponsive to systemic hypoxia at a level that increases VEGF mRNA in even the resting gastrocnemius of the same species is not clear, but without the ability to measure intracellular $\mathrm{Pa}, \mathrm{O}_{2}$ in either case, it is not possible to provide a clear answer. Another weakness of the present protocol is that a limb muscle to clarify the effect of systemic hypoxia was not included.
The findings of AMEREDEs et al. [20] support the present results demonstrating that the diaphragm is relatively insensitive to short (24 min) changes in $\mathrm{O}_{2}$ supply during moderate hypoxia (inspiratory oxygen fraction $\left.\left(F \mathrm{I}, \mathrm{O}_{2}\right)=0.13\right)$. They speculated that this could reflect a difference in either the metabolic or blood flow characteristics of shortening contractions of the diaphragm. This could be visualized better if the geometry of the diaphragm is considered, which is like a dome (curved) in contrast to the more linear nature of the skeletal muscles. Diaphragmatic blood flow is enhanced at shorter muscle lengths [21], and active muscle shortening may optimize capillary configuration [22]. Thus, arterial hypoxia could not accurately reflect the partial pressure of $\mathrm{O}_{2}$ in the diaphragmatic muscle fibres. Another explanation for the different diaphragmatic response to systemic hypoxaemia than that seen in the gastrocnemius could be that VEGF in the diaphragm is regulated by another mechanism namely, the adenosine pathway [23].

The lack of change in TGF- $\beta_{1}$ after active ventilation was not unexpected. The study of BREEN et al. [9] showed a higher signal for VEGF and bFGF than TGF- $\beta_{1}$ after exercise. In addition, the study of RocA et al. [11] showed an increase in the mRNA of VEGF after electrical stimulation only and not in mRNA levels of bFGF and TGF- $\beta_{1}$. Although those results were obtained in another species (canine) and under different experimental conditions, it is apparent that the major angiogenic factor gene response for the skeletal and respiratory muscles is VEGF. The short half-life of VEGF mRNA levels in vascular smooth muscles [24] could explain the acute increase in VEGF as an early response to increased metabolic needs.

Basic FGF, although a direct angiogenic factor, has a broader cell-type specificity. It has been speculated that $\mathrm{bFGF}$ may represent a longer-term response to muscle stimulation [8]. The present experiments only lasted $1 \mathrm{~h}$, and may be insufficient to test this hypothesis. However, the smaller increase seen in bFGF than in VEGF is in agreement with this suggestion.

It is well known that VEGF expression is regulated at the transcriptional [25], post-transcriptional [26-28] and translational [29] levels. VEGF upregulation by hypoxia has been demonstrated both in vitro and in vivo and induces neovascularization [30]. Furthermore, there have been some studies reporting that stretch upregulates VEGF expression in the heart [31] and in cultured cardiac myocytes [32]. This stretch induction of VEGF appears to be mediated in part by TGF- $\beta$. However, this network interaction between the various angiogenic factors is not fully understood and the results of this study provide a rationale for further studies of the regulatory regions in the genes of angiogenic growth factor. In particular, further experiments are needed to investigate the relationship between mRNA levels and the protein levels of these angiogenic factors in the diaphragm.

Overall, angiogenic growth factors serve an important physiological role of mediating the dynamic vascularization of tissues to meet metabolic, nutritional and oxygen supply demands. The results of this study suggest that upregulation of VEGF mRNA levels is an early response to increased mechanical tension in 
the diaphragm resulting from increased ventilation. Furthermore, these data show that angiogenic growth factor gene expression in the diaphragm is sensitive to diaphragmatic load, and this raises the future possibility that therapeutic enhancement of diaphragmatic vascular growth in patients with respiratory failure could contribute to their recovery (weaning from a ventilator). While further work would have to be done to evaluate this hypothesis, studies of the myocardium $[33,34]$ and of ischaemic vascular disease [35] have shown that targeted growth factor administration improves local blood supply [36-40].

In summary, the results of this study showed that active increases of ventilation by hypoxia and/or hypercapnia upregulate vascular endothelial growth factor and basic fibroblast growth factor messenger ribonucleic acid levels in the diaphragm, and this increase is proportional to minute ventilation. In paralysed mechanically-ventilated animals at similar arterial blood gas and ventilatory levels, no change in messenger ribonucleic acid levels of any of the three angiogenic factors studied was observed. Thus, moderate hypoxia and passive shortening of the muscle had no additional effect. To conclude, angiogenic gene responses of the diaphragm depend on active contraction of the diaphragm.

\section{References}

1. Andersen P, Henriksson J. Capillary supply of the quadriceps femoris muscle of man: adaptive response to exercise. J Physiol (Lond) 1977; 270: 677-690.

2. Bebout DE, Hogan MC, Hempleman SC, Wagner PD. Effects of training and immobilisation on $\mathrm{VO}_{2}$ and $\mathrm{DO}_{2}$ in dog gastrocnemius muscle in situ. $J$ Appl Physiol 1993; 74: 1697-1703.

3. Brodal P, Ingjer F, Hermansen L. Capillary supply of skeletal muscle fibers in untrained and endurancetrained men. Am J Physiol 1977; 232: H705-H712.

4. Hudlicka O, Brown M, Egginton S. Angiogenesis in skeletal and cardiac muscle. Physiol Rev 1992; 72: 369 417.

5. Iruela-Arispe ML, Hasselaar P, Sage H. Differential expression of extracellular proteins is correlated with angiogenesis in vitro. Lab Invest 1991; 64: 174-186.

6. Leung DW, Cachianes G, Kuang WJ, Goeddel DV, Ferrara N. Vascular endothelial growth factor is a secreted angiogenic mitogen. Science 1989; 246: 13061309.

7. Goto F, Goto K, Weindel K, Folkman J. Synergistic effects of vascular endothelial growth factor and basic fibroblast growth factor on the proliferation and cord formation of bovine capillary endothelial cells within collagen gels. Lab Invest 1993; 69: 508-517.

8. Merwin JR, Anderson JM, Kocher O, Van Itallie CM, Madri JA. Transforming growth factor beta 1 modulates extracellular matrix organisation and cellcell junctional complex formation during in vitro angiogenesis. J Cell Physiol 1990; 142: 117-128.

9. Breen EC, Johnson EC, Wagner H, Tseng HM, Sung LA, Wagner PD. Angiogenic growth factor mRNA responses in muscle to a single bout of exercise. $J$ Appl Physiol 1996; 81: 355-361.

10. Hang J, Kong L, Gu JW, Adair TH. VEGF gene expression is upregulated in electrically stimulated rat skeletal muscle. Am J Physiol 1995; 269: H1827H1831.

11. Roca J, Gavin TP, Jordan M, et al. Angiogenic growth factor mRNA responses to passive and contractioninduced hyperperfusion in skeletal muscle. $J$ Appl Physiol 1998; 85: 1142-1149.

12. Bartlett D Jr, Tenney SM. Control of breathing in experimental anemia. Respir Physiol 1970; 10: 384 395.

13. Chomczynski P, Sacchi N. Single-step method of RNA isolation by acid guanidinium thiocyanate-phenolchloroform extraction. Anal Biochem 1987; 162: 156159.

14. Feinberg AP, Vogelstein B. "A technique for radiabeling DNA restriction endonuclease fragments to high specific activity". Addendum Anal Biochem 1984; 137: 266-267.

15. Qian SW, Kondaiah P, Roberts AB, Sporn MB. cDNA cloning by PCR of rat transforming growth factor beta-1. Nucleic Acids Res 1990; 18: 3059.

16. Gu JW, Adair TH. Hypoxia-induced expression of VEGF is reversible in myocardial vascular smooth muscle cells. Am J Physiol 1997; 273: H628-H633.

17. Forsythe JA, Jiang $\mathrm{BH}$, Iyer $\mathrm{NV}$, et al. Activation of vascular endothelial growth factor gene transcription by hypoxia-inducible factor 1. Mol Cell Biol 1996; 16 : $4604-4613$.

18. Levy NS, Goldberg MA, Levy AP. Sequencing of the human vascular endothelial growth factor (VEGF) 3' untranslated region (UTR): conservation of five hypoxia-inducible RNA-protein binding sites. Biochim Biophys Acta 1997; 1352: 167-173.

19. Liu Y, Cox SR, Morita T, Kourembanas S. Hypoxia regulates vascular endothelial growth factor gene expression in endothelial cells. Identification of a $5^{\prime}$ enhancer. Circ Res 1995; 77: 638-643.

20. Ameredes BT, Julian MW, Clanton TL. Muscle shortening increases sensitivity of fatigue to severe hypoxia in canine diaphragm. $J$ Appl Physiol 1991; 71: 2309-2316.

21. Supinski GS, Bark H, Guanciale A, Kelsen SG. Effect of alterations in muscle fiber length on diaphragm blood flow. J Appl Physiol 1986; 60: 1789-1796.

22. Groom AC, Ellis CG, Potter RF. Microvascular geometry in relation to modelling oxygen transport in contracted skeletal muscle. Am Rev Respir Dis 1984; 129: S6-S9.

23. Gu JW, Brady AL, Anand V, Moore MC, Kelly WC, Adair TH. Adenosine upregulates VEGF expression in cultured myocardial vascular smooth muscle cells. $\mathrm{Am}$ J Physiol 1999; 277: H595-H602.

24. Li J, Perrella MA, Tsai JC, et al. Induction of vascular endothelial growth factor gene expression by interleukin-1 beta in rat aortic smooth muscle cells. $J$ Biol Chem 1995; 270: 308-312.

25. Levy AP, Levy NS, Wegner S, Goldberg MA. Transcriptional regulation of the rat vascular endothelial growth factor gene by hypoxia. J Biol Chem 1995; 270 : 13333-13340.

26. Levy AP, Levy NS, Goldberg MA. Post-transcriptional regulation of vascular endothelial growth factor by hypoxia. J Biol Chem 1996; 271: 2746-2753.

27. Levy NS, Chung S, Furneaux H, Levy AP. Hypoxic stabilization of vascular endothelial growth factor mRNA by the RNA-binding protein HuR. J Biol Chem 1998; 273: 6417-6423. 
28. Dibbens JA, Miller DL, Damert A, Risau W, Vadas MA, Goodall GJ. Hypoxic regulation of vascular endothelial growth factor mRNA stability requires the cooperation of multiple RNA elements. Mol Biol Cell 1999; 10: 907-919.

29. Stein I, Itin A, Eiuat P, Skaliter R, Grossman Z, Keshet E. Translation of vascular endothelial growth factor mRNA by internal ribosome entry: implications for translation under hypoxia. Mol Cel Biol 1998; 18: 3112-3119.

30. Cao Y, Linden P, Shima D, Browne F, Folkman J. In vivo angiogenic activity and hypoxia induction of heterodimers of placenta growth factor/vascular endothelial growth factor. $J$ Cin Invest 1996; 98: 2507-2511.

31. Li J, Hampton T, Morgan JO, Simons M. Stretchinduced VEGF expression in the heart. J Clin Invest 1997; 100: 18-24.

32. Seko Y, Seko Y, Takahashi N, Shibuya M, Yazaki Y. Pulsatile stretch stimulates vascular endothelial growth factor (VEGF) secretion by cultured rat cardiac myocytes. Biochem Bioph Res Commun 1999; 254: 462-465.

33. Miyataka M, Ishikawa K, Katori R. Basic fibroblast growth factor increased regional myocardial blood flow and limited infarct size of acutely infarcted myocardium in dogs. Angiology 1998; 49: 381-390.

34. Losordo DW, Vale PR, Symes JF, et al. Gene therapy for myocardial angiogenesis: initial clinical results with direct myocardial injection of phVEGF165 as role therapy for myocardial ischemia. Circulation 1998; 98: 2800-2804.

35. Takeshita S, Zheng LP, Brogi E, et al. Therapeutic angiogenesis. A single intraarterial bolus of vascular endothelial growth factor augments revascularization in a rabbit ischemic hind limb model. J Clin Invest 1994; 93: 662-670.

36. Tsurumi Y, Kearney M, Chen D, et al. Treatment of acute limb ischemia by intramuscular injection of vascular endothelial growth factor gene. Circulation 1997; 96: (Suppl. 9), 382-388.

37. Sellke FW, Laham RJ, Edelman ER, Pearlman JD, Simons M. Therapeutic angiogenesis with basic fibroblast growth factor: technique and early results. Ann Thorac Surg 1998; 65: 1540-1544.

38. Hopkins SP, Bulgrin JP, Sims RL, Bowman B, Donovan DL, Schmidt SP. Controlled delivery of vascular endothelial growth factor promotes neovascularization and maintains limb function in a rabbit model of ischemia. J Vasc Surg 1998; 27: 886-894.

39. Springer ML, Chen AS, Kraft PE, Bednarski M, Blau HM. VEGF gene delivery to muscle: potential role for vasculogenesis in adults. Mol Cell 1998; 2: 549-558.

40. Yang HT, Ceschenes MR, Ogilvie RW, Terjung RL. Basic fibroblast growth factor increases collateral blood flow in rats with femoral arterial ligation. Circ Res 1996; 79: 62-69. 